\section{Examining Teacher Mathematics-related Beliefs and Problem-solving Knowledge for Teaching: Evidence from Indonesian Primary and Secondary Teachers}

\author{
Tatag Yuli Eko Siswono ${ }^{a,}{ }^{,}$, Ahmad Wachidul Kohar ${ }^{\mathrm{b}}$, Sugi Hartonoc, \\ Abdul Haris Rosyidid, Ika Kurniasarie, Karim Karim ${ }^{f}$
}

$\begin{array}{ll}\text { Received: } & \text { 20 February } 2019 \\ \text { Revised: } \quad 22 \text { April } 2019 \\ \text { Accepted: } \quad \text { 14 June } 2019 \\ \text { ISSN: 1307-9298 } \\ \text { Copyright (C) IEJEE } \\ \text { www.iejee.com }\end{array}$

DOI: 10.26822/iejee.2019553346

\begin{abstract}
This paper reports a two-year research project studying Indonesian primary and secondary teachers' mathematics-related beliefs (MrB) and mathematical problem-solving knowledge for teaching (MPSKT). In the first year, a quantitative study involving 80 primary teachers, 70 lower secondary school, and 55 upper secondary schools from four districts in East Java province, Indonesia was carried out to examine whether there is a difference between the MrB and the MPSKT among them. In the second year, a multiple case study involving ten primary teachers and 13 lower secondary teachers was conducted to understand their MrB and MPSKT through some particular issues related to three domains of MrB: nature of mathematics, mathematics teaching, mathematics learning. Results indicate that there is no significant difference of MrB between primary and secondary teachers, while there is a significant difference between the MPSKT of primary teachers and secondary teacher. Findings also suggest that inconsistencies not only occur between the three domains of MrB but also occurs between particular issues discussed within one domain. Also, this study highlights that teacher beliefs about nature of mathematics were mainly influenced by teachers' experience when learning mathematics during their schooling experience while teacher beliefs about teaching and learning were mainly influenced by the demand of current reform of mathematics curriculum.
\end{abstract}

Keywords: Mathematics-Related Beliefs, Problem-Solving Knowledge For Teaching, Instrumentalist, Platonist, Problem-Solving, Indonesian Teacher

\section{Introduction}

Knowledge and beliefs of teachers are still becoming areas of considerable current research activity in mathematics education (Beswick, 2012; Liljedahl, 2010; Xenofontos, 2018). Across nations, teacher beliefs have been assessed to understand the influence of cultural aspect toward teachers' view and performance of teaching practice (see, e.g. Andrews \& Hatch, 2000; Cai \& Wang, 2010; Wang \& Cai, 2007; Xenofontos, 2018). Meanwhile, teacher mathematical knowledge have been assessed through international surveys with a significant number of samples such as TEDS-M (Teacher Education and Development Study in Mathematics) (Tatto et al., 2013) to compare the teacher performance on mathematical knowledge for teaching and single-nation studies (e.g. Ekawati et al, 2015; Siswono et al, 2016; 2017) with a smaller number of samples through qualitative or quantitative studies.

In Indonesia, teacher beliefs and knowledge have begun to get attention from educational researchers, particularly to understand the initial assessments as resources for upgrading the quality of Indonesian mathematics teachers (Ekawati et al, 2015; Purnomo et al., 2016; Purnomo, 2017; Siswono et al., 2016). This effort is to answer the challenge of the significant curricular reform for all school levels for primary, junior high school, and senior high school which is currently undergoing since the year 2013. Such a reform, as found in the previous curriculum, keep giving focus on improving students' problem-solving (MoE, 2016). However, the educational researchers through their national single-studies reported teachers' weaknesses on problem-solving content and pedagogical knowledge (see, e.g. Siswono et al, 2016), the knowledge which direct teachers hold problem-solving instruction
(Chapman, 2015). Also, several reports reveal teachers' inconsistent beliefs toward teachers' teaching practice (Purnomo et al., 2016; Siswono et al., 2017; Siswono et al., 2018a), and teachers' traditional beliefs about the nature of mathematics which influence more dominantly than the other domains of beliefs against instructional practices (Purnomo, 2017). Thus, the reform of curriculum needs changing teachers' beliefs because teachers behavior regarding their use of new resources mandated by the curriculum, as Handal and Herrington (2003) argued, will be cosmetic, which means that the behaviors do not indicate the manifestation of the expected principles of the curriculum reform.

Teacher beliefs and knowledge are two distinct concepts the differences around conviction and consensuality (Thompson, 1992). First, beliefs can be held with varying degrees of confidence, while general knowledge is not thought of in this way. For example, while someone might say that he believes in something strongly, he will be less likely to talk about knowing facts actively. Second, beliefs are not consensual, while knowledge is consensual. That is, someone is generally aware that other people may believe differently and that their thought is indisputable, while concerning knowledge, people find general agreement about procedures to evaluate and assess their validity.

Despite these two are different, there is a relationship between teacher knowledge and beliefs regarding mathematics instruction. Along with teacher mathematical knowledge, teacher mathematics-related beliefs such as beliefs about nature of mathematics, mathematics teaching, and mathematics learning also become variables that play a role in guiding that knowledge to create meaningful mathematics learning (Purnomo, 2017). Teacher mathematics-related

\footnotetext{
a,*Corresponding Author: Tatag Yuli Eko Siswono, Departement of Mathematics, Universitas Negeri Surabaya, Surabaya, Indonesia. E-mail: tatagsiswono@unesa.ac.id

${ }^{b}$ Ahmad Wachidul Kohar, Departement of Mathematics, Universitas Negeri Surabaya, Surabaya, Indonesia. E-mail:ahmadw.kohar@gmail.com

cSugi Hartono, Departement of Mathematics, Universitas Negeri Surabaya, Surabaya, Indonesia. E-mail: sugihartonounesa@gmail.com

dAbdul Haris Rosyidi, Departement of Mathematics, Universitas Negeri Surabaya, Surabaya, Indonesia. E-mail: abdulharis@unesa.ac.id

elka Kurniasari, Departement of Mathematics, Universitas Negeri Surabaya, Surabaya, Indonesia. E-mail: ikakurniasari@unesa.ac.id

fKarim Karim, Departement of Mathematics, Universitas Lambung Mangkurat, Banjarmasin, Indonesia. E-mail: karim_fkip@ulm.ac.id 
beliefs have been researched to have strong interactions with knowledge in shaping teacher teaching practices with varying degrees given on certain types of knowledge or beliefs in different situations (Bray, 2011). While teacher knowledge appeared to drive the quality of teachers' responses to student performances in class discussions, teacher beliefs seemed most related to how teachers structured class discussions (Bray, 2011). Concerning how beliefs and knowledge interact, Ren and Smith (2017) suggest the potential role of teachers' mathematical knowledge for teaching in improving teachers' mathematical beliefs. Such an interaction is in line with the finding of Siswono et al. (2017) through a case study reporting that teachers' insufficient knowledge about problem-solving is consistent with teachers' traditional beliefs.

Regarding teacher beliefs, much research gives attention to the role of cultural and geographical impact on teachers' mathematics-related beliefs (see, e.g. Correa et al., 2008; Wang \& Cai, 2007; Xie \& Cai, 2018), and gender impact on teacher beliefs (e.g. Spangenberg \& Myburgh, 2017). However, only a relatively few reported findings which figure out how particular school grade level inform the unique characteristics of teachers' beliefs compared to another different grade level of teaching. One of such few discussion was reported by Purnomo et al. (2018) through their study involving Indonesian teachers finding that there is no significant difference on beliefs held by teachers with different grade level taught in the same scope of school grade level, i.e. primary school. Beyond this scope, this present study aims to examine how teachers at different school grade, i.e. primary, lower secondary, and upper secondary, as it goes in Indonesian educational system, differ regarding their mathematics-related beliefs. This is to follow the recommendation from Xenofontos (2018) suggesting to examine further the extent to which teachers' beliefs are similar or different across school levels, within the same cultural context and educational system. Regarding teacher knowledge, in the same school grade level, for example, the study of $\mathrm{Ng}$ (2011) found that there were no significant differences in the teacher knowledge scores between teachers who had taught lower primary grades and those who had taught upper primary classes. However, they do not analyze the comparison between teachers in primary school and secondary school simultaneously.

This study aims to reveal whether there is a relation between MrB and MPSKT of teachers across school level of teaching grade as well as analyze particular issues within domains of MrB and components of MPSKT held by the teachers regarding Indonesian context. In detail, the aims are to (1) examine whether there are any significant differences between the MrB and the MPSKT of primary teachers, lower-secondary school, and upper-secondary school teachers, as well as (2) analyze their beliefs about the nature of mathematics, mathematics teaching, and mathematics learning, and the problem-solving content knowledge and problem-solving pedagogical knowledge.

\section{Theoretical Framework}

Mathematics-Related Beliefs: Nature of Mathematics, Mathematics Teaching, and Learning

There is no standard taxonomy used to define the conceptions of the nature of mathematics although relevant literature is quite numerous. Cai and Wang (2009) argued that teachers' conception of the nature of mathematics could be viewed as teacher's conscious or subconscious beliefs, meanings, rules, concepts, mental images, and preferences regarding the discipline of mathematics. In this study, we used the categorization of Ernest (1989) for the nature of mathematics. The instrumentalists pay more attention to the functions of mathematics knowledge in the external world (functional perspectives), which is a collection of unrelated facts, rules, and skills. Platonists emphasize the complexity of the internal structure of the knowledge itself (structural perspectives), which is seen as a static and unified body of knowledge, while problem-solving view emphasizes the dynamic and creative properties of mathematics as a human invention.

Ernest (1989) accentuates that teachers' view of the nature of mathematics is the most essential because it affects the other two domains of mathematics-related beliefs: mathematics teaching and learning. Therefore, researching about teacher view of nature mathematics, scholars often also necessary to study teachers' view of mathematics teaching and mathematics learning (e.g. Siswono et al., 2016; 2017; Xenofontos, 2018). Thus, this paper concern on examining primary and secondary teachers' view of those three beliefs.

Mathematics teaching beliefs, as Thompson (1992) suggested, include teacher role, students' role, desirable instructional approaches and emphases, appropriate classroom activities, legal, mathematical procedures, and acceptable outcomes of instruction. Furthermore, at least there are three distinctive views: learner-focused, content-focused with an emphasis on performance, content-focused with an emphasis on understanding. Essentially, some researchers also correspond to each of Thompson's categories of views with 'teacher-centered' teaching beliefs and 'student-centered teaching beliefs' (Correa et al., 2008). While 'teacher-centered' view corresponds to 'content-focused' view with an emphasis on performance, the idea of 'student-centered' teaching view is aligned with 'learner-focused' view. Regarding mathematics, it includes the process of learning mathematics, what behaviors and mental activities are involved on the part of the learner, and what constitutes appropriate and prototypical learning activities (Ernest, 1989). Beswick (2005) has summarised this conception into a table which compares teacher beliefs about mathematics (Ernest, 1989), mathematics learning (Ernest, 1989) and mathematics teaching (Van Zoest et al., 1994). She argues that there are three groups of hierarchical view of those three beliefs which is considered theoretically consistent each other, i.e. (1) Instrumentalist - skill mastery - content focused with an emphasis on performance, (2) Platonist - active construction of understanding - content focused with an emphasis on understanding, and (3) problem-solving - learner focussed - autonomous exploration of own interest.

Mathematics Teachers' Knowledge for Teaching Problem-Solving

There is a consensus that teachers' knowledge about mathematical problem-solving is not merely about having proficiency in solving a mathematical problem. Instead, it also covers knowledge about how to become a good problem-solvers as well as how to help students become better problem solvers. In this sense, Chapman (2015) has proposed the so-called 'mathematical problem-solving knowledge for teaching (MPSKT)' that can guide teachers to teach problem-solving. In general, MPSKT consist of (1) problem-solving content knowledge (knowledge of problem, problem-solving, and problem posing), (2) pedagogical problem-solving (knowledge of students as problem solvers and instructional practice for problem-solving), and (3) knowledge of affective factors and beliefs (nature and impact of productive and unproductive factors on learning and teaching problem-solving).

This paper primarily concerns MPSKT by Chapman (2015) although not all the components were examined to teachers. This is due to the complex issues which are interde- 
pendent within MPSKT. Thus, we only highlight some elements of the first two components of MPSKT, covering, for examples, the nature of the mathematical problem and problem-solving, problem-solving process and strategies, and organizing problem-solving instruction.

\section{Method}

The Research Design

This project employs a mixed method with sequential design, in which data that are collected and examined in one stage inform the data collected in the next phase (Ary et al., 2018). In this study, the authors draw on the interpretation of the findings from a quantitative study, followed by qualitative research through a collective case study methodology. In particular, the quantitative research was carried out to describe the results of the aim no 1 , while the qualitative research was carried out to answer the describe the results of the aim no 2 . All the answers were then reported in two separate sets (qualitative and quantitative) of coherent wholes.

\section{First-Year Research Design}

The quantitative research was employed by collecting data on teachers' responses on MrB and MPSKT through a set of questionnaire. The items used in such questionnaire were the same as those in the questionnaire we used in our previous single-study involving only secondary teachers as study samples (see Siswono et al., 2016). The questionnaire consisted of 18 multiple choices questions (3 $\mathrm{MrB}$ items and 15 MPSKT items). Each item provided 4 to 17 choices. Some of those questions had a large number of choices because of a need to cover as many as possibilities of teacher's responses. For instance, the question item for MrB related to mathematics learning: "In my opinion, the best way students should learn mathematics are..." has 12 choices consisting 4 options indicating 'skill mastery' view (score 1), 4 options indicating 'active construction of understanding' view (score 2), and 4 items indicating 'autonomous exploration of own interest' view (score 3). Thus, the teacher could choose more than one options. Meanwhile, MPSKT items were derived from Chapman's category described in table 1 . The groups are (a) problem solving content knowledge: meaning of problem (1 item), types of problem (1 item), problem solving as instruction (1 item), problem solving steps (3 items), problem-solving strategies (2 items), and (b) pedagogical problem solving knowledge: instructional practice of problem solving (3 items), and designing problem solving task (3 items).

The score varies to show the level of understanding from 1.00 (do not understand), to 3.00 (fully understand), while the other scores vary to show the level of beliefs on mathematical problem solving from 1.00 (instrumentalist view) to 3.00 (problem-solving view). The score is given to each participant on each question based on the following formula (Siswono et al.,2016).

\section{Score $=\frac{\text { obtained total score }}{\text { number of selected options }}$}

In detail, we have adopted a guideline to categorize these levels as shown in table 1 from Siswono et al. (2016).

To confirm the validity of the questionnaire, all the items tested are significantly valid, with the coefficient validity of each of the items is interpreted as at least medium $(.253<$ $\left.r_{x y}<.511\right)$, and the reliability coefficient (.60) as medium as well. Data were then analyzed by employing one-way ANOVA which were used to investigate differences of MrB and MPSKT among teachers in terms of the grade level of teaching. The assumptions were conducted in terms of normality and homogeneity of data before doing such a one-way ANOVA test.

Table 1. Scoring category level of teachers' understanding and beliefs (Siswono et al., 2016)

\begin{tabular}{lll}
\hline Score $(\mathrm{S})$ & Level of MrB & $\begin{array}{l}\text { Level of } \\
\text { understanding MPSKT }\end{array}$ \\
\hline $1.00 \leq S \leq 1.67$ & $\begin{array}{l}\text { as instrumentalist } \\
\text { view/skill mastery/ } \\
\text { content-perfor- } \\
\text { mance }\end{array}$ & not understand (NU) \\
\hline \multirow{3}{*}{$\begin{array}{l}\text { as platonist view/ } \\
\text { active construction } \\
\text { of understanding/ } \\
\text { content-under- }\end{array}$} & $\begin{array}{l}\text { partially understand } \\
\text { (PU) }\end{array}$ \\
\hline & $\begin{array}{l}\text { as problem-solving } \\
\text { view/learner own } \\
\text { interest/learner } \\
\text { focused }\end{array}$ & fully understand (FU) \\
\hline
\end{tabular}

Second-Year Research Design

A multiple case study was undertaken in the qualitative research. A simultaneous cross-case analysis approach was conducted to illuminate patterns across cases and increase the potential for generalizing beyond particular cases (Yin, 2003). The cases were the MrB and the MPSKT of all teacher participants. Such an approach followed Stake's (2005) opinion arguing that in collective case studies, cases are chosen because it is believed that understanding them will lead to better understanding, perhaps better theorizing about a still more extensive collection of cases. Using a constant comparative method to focus data collection and analysis (Glaser, 2017), interpretive case studies on each of primary and secondary teacher participants were developed using data collected through a semi-structured interview about MrB and MPSKT.

Regarding MrB interview, the teacher participants were provided with a set of incomplete statements each of which has three options in which they were asked to select only one as the best options representing their beliefs related to the proposed issue. For example, the incomplete statement, "In motivating students to learn mathematics, I prefer to..." has three options: (1) give some rewards since it is an excellent strategy to make students keep on doing mathematics tasks, (2) provide some rewards if only students work actively in what I asked them to do, and (3) give challenging and interesting mathematical tasks, regardless of whether they will get any rewards or not. Options (1), (2), and (3) respectively represent the category of beliefs: content-performance, content-understanding, and learner focused. Once the teacher participants selected one of the options, they were prompted to give a reason why selected those options and how they compare their options chosen with two other unselected options. Overall, Table 2 shows some particular issues drawing on Mr-B, some of which were adapted from Cai and Wang (2009) and derived from Beswick's summary (2005) and MPSKT, which were derived from Chapman's (2015) categories of MPSKT.

The MPSKT interview items, in particular, encouraged them to answer direct questions posed by the interviewers (the authors themselves). For example, in relation to the issue about nature of mathematical problems, the teacher participants were provided with three mathematical questions having different concern on characteristics of mathematical problem such as has no readily available procedure for finding the solution as well as challenges and attracts students to work out the questions, and by responding and arguing whether each of them is a problem for their students. 
Table 2. Issues related to MrB and MPSKT discussed with teacher participants

\begin{tabular}{|c|c|c|c|}
\hline Domain of MrB & Mr-B issues & Categories of MPSKT & MPSKT issues \\
\hline $\begin{array}{l}\text { Nature of } \\
\text { mathematics }\end{array}$ & $\begin{array}{l}\text { - Definition of mathematics } \\
\text { - mathematical skills need to be ad- } \\
\text { dressed by someone, } \\
\text { - the relationship between mathematics } \\
\text { and real-life problem, }\end{array}$ & $\begin{array}{l}\text { Problem-solving } \\
\text { content knowledge }\end{array}$ & $\begin{array}{l}\text { - nature of mathematical problem } \\
\text { - types of mathematical problem } \\
\text { - problem-solving process } \\
\text { - problem-solving strategies } \\
\text { - nature of problem-solving } \\
\text { - problem-posing }\end{array}$ \\
\hline $\begin{array}{l}\text { Mathematics } \\
\text { teaching }\end{array}$ & $\begin{array}{l}\text {-how to improve problem-solving skill, } \\
\text {-the use of mathematical formula, } \\
\text { •the use of a calculator in solving the } \\
\text { problem, } \\
\text {-students should learn about various } \\
\text { strategies, }\end{array}$ & $\begin{array}{l}\text { problem-solving } \\
\text { pedagogical } \\
\text { knowledge }\end{array}$ & $\begin{array}{l}\text { - knowledge of students' difficulties on } \\
\text { problem-solving } \\
\text { - knowledge of teaching problem-solving } \\
\text { task }\end{array}$ \\
\hline $\begin{array}{l}\text { Mathematics } \\
\text { learning }\end{array}$ & $\begin{array}{l}\text { •the role of the teacher in helping } \\
\text { students to solve the task, } \\
\text { - the precise time to introduce an } \\
\text { applied problem-solving task, } \\
\text { - sources of problems used in } \\
\text { instruction, } \\
\text { - how to clarify students' } \\
\text { misunderstanding on a problem- } \\
\text { solving-based instruction, } \\
\text { - the best way of teaching a } \\
\text { problem-solving task } \\
\text { - the dynamic characteristics of } \\
\text { strategies and solutions in solving a } \\
\text { problem-solving task }\end{array}$ & $\begin{array}{l}\text { affective factors and } \\
\text { beliefs }\end{array}$ & --- \\
\hline
\end{tabular}

\section{Participants}

Overall, this study took place at four districts: Surabaya, Mojokerto, Sidoarjo, and Gresik in East Java Province, Indonesia where all the participants were recruited from those four districts as well. At the first-year research, this project involved 80 primary teachers, 70 lower secondary school, and 55 upper secondary schools. All those teachers were from schools in urban and rural areas, having teaching experiences from 5 to 40 years, all of which represent the various background of samples.

Meanwhile, in the second year, this project was conducted by recruiting ten primary teachers and 13 lower secondary teachers. These numbers were chosen since we no longer got relatively new issues emerged from the teachers' responds at those number of interviews. This principle followed the opinion of Fusch and Ness (2015) arguing that the number of meetings needed to reach data saturation could be based on the extent to which the number of interviews decided by researchers can obtain additional new information and makes further coding is no longer feasible. The teacher participants from upper-secondary school were no longer involved in the second-year research since the recommendation of the results of the first-year research (presented in the results section) finding that there is no any significant differences between MrB and MPSKT between the two. Therefore, they could be categorized into one group of teachers. Thus, we selected lower-secondary teachers as representative of this group.

Furthermore, the number of teachers in the second-year research is smaller than that in the first-year research due to the concern of employing a qualitative approach which in this case need not large samples. Besides, the teachers involved in the first-year research differ from those involved in the second-year research. Table 3 presents biographical information about the participants completed with their pseudonyms, gender ( 15 female, 8 male) and years of teaching experiences $(M=17.9, S D=11.3)$ indicating the various background of samples.

Table 3. The participants of the second-year research

\begin{tabular}{rrrrlr}
\hline \multicolumn{2}{c}{ Primary teachers } & \multicolumn{4}{c}{ Secondary teachers } \\
\hline Pseudonym & Gender & $\begin{array}{r}\text { Years of } \\
\text { teaching } \\
\text { experience }\end{array}$ & Pseudonym & Gender & $\begin{array}{r}\text { Years of } \\
\text { teaching } \\
\text { experience }\end{array}$ \\
\hline P1 & female & 10 & S1 & male & 35 \\
\hline P2 & male & 30 & S2 & female & 40 \\
\hline P3 & female & 18 & S3 & male & 34 \\
\hline P4 & male & 5 & S4 & male & 12 \\
\hline P5 & female & 8 & S5 & male & 7 \\
\hline P6 & female & 12 & S6 & female & 21 \\
\hline P7 & female & 9 & S7 & female & 6 \\
\hline P8 & female & 12 & S8 & female & 8 \\
\hline P9 & female & 9 & S9 & male & 32 \\
\hline P10 & male & 36 & S10 & female & 14 \\
\hline & & & S11 & female & 27 \\
\hline & & & S12 & female & 12 \\
\hline & & & S13 & female & 16 \\
\hline
\end{tabular}

The interview was conducted individually, lasted on average 45-60 minutes for MrB and 30-45 minutes for MPSKT. Data analysis was carried out by firstly reducing data, dis- 
playing data, and finally drawing conclusions and verification (Miles \& Huberman, 1994). The conclusion was sought to understand the comparison of the MrB and MPSKT between primary and secondary teachers, particularly in the context of Indonesia. The data derived from the second-year research were used in this paper to illustrate the quantitative findings from the first-year research as well as to provide a general overview of the orientations of groups of teachers regarding MrB and MPSKT.

\section{Results}

\section{Teachers'MrB and MPSKT: Quantitative Results}

Prior to ANOVA tests, normality tests were performed first to determine whether the sample data taken has followed the distribution of normal distribution. The normality test is given in table 4 .

The table indicates that all the data collected from teachers' MrB and MPSKT were normally distributed based on Kolmogorov-Smirnov test as indicated by the value of $p$ which is all more than .05. Therefore, the data were examined in the Levene statistic test to investigate the homogeneity of variances.
Table 5 shows the result of Levene statistic which examines whether the samples of data were taken from the population having the same variances. The result indicates that both the significances $p$ for the data of MPSKT and $\mathrm{MrB}$ are more than .05, which means they meet the homogeneity of variances. Therefore, the statistical test could be continued with the ANOVA test.

The ANOVA test shown in table 6 indicates that there is a statistically significant difference among the MPSKT of primary teachers, lower-secondary teachers, and upper-secondary teachers $(F=11.279, p=.00<.05)$, while there is not a statistically significant difference among the MrB of primary teachers, lower-secondary teachers, and upper-secondary teachers $(F=1.527, p=.22>.05)$. Tukey's HSD test was examined to identify means that are significantly different from each other; This is presented in the table as follows.

When table 7 is examined, it can be seen that the MPSKT of primary teachers and lower-secondary teachers is significantly different $(p=.00<.05)$. Also, the MPSKT of primary teachers and upper-secondary teachers was significantly different $(p=.002<.05)$. Meanwhile, the other pair of the group, lower-secondary teachers and upper-second-

Table 4. Test of Descriptive Statistic and Normality of MrB and MPSKT

\begin{tabular}{lllllrrr}
\hline & School Grade & Mean & Interpretation & & $S D$ & \multicolumn{2}{c}{ Kolmogorov-Smirnov } \\
\hline \multirow{3}{*}{ MrB } & & & & Statistic & $d f$ & $p$ \\
\cline { 2 - 8 } & Primary teacher & 2.24 & Platonist & .442 & 0.085 & 80 & .200 \\
\cline { 2 - 8 } & Lower-secondary teacher & 2.13 & Platonist & .413 & 0.080 & 70 & .200 \\
\cline { 2 - 8 } & Upper-secondary teacher & 2.27 & Platonist & .335 & 0.106 & 55 & .184 \\
\hline \multirow{3}{*}{ MPSKT } & Primary teacher & 2.30 & Partially understand & .195 & 0.630 & 80 & .200 \\
\cline { 2 - 8 } & Lower-secondary teacher & 2.49 & Fully understand & .187 & 0.055 & 70 & .200 \\
\cline { 2 - 8 } & Upper-secondary teacher & 2.46 & Fully understand & .167 & 0.067 & 55 & .200 \\
\hline
\end{tabular}

Table 5. Test of Homogeneity of Variances

\begin{tabular}{lrrrr}
\hline & Levene Statistic & $d f 1$ & $d f 2$ & $p$ \\
\hline MrB & 2.464 & 2 & 202 & .088 \\
\hline MPSKT & 1.343 & 2 & 202 & .263 \\
\hline
\end{tabular}

Table 6. ANOVA results

\begin{tabular}{llrrrr}
\hline & & Sum of Squares & $d f$ & Mean Square & $F$ \\
\hline \multirow{3}{*}{ MrB } & Between Groups & 0.525 & 2 & 0.262 & 1.527 \\
\cline { 2 - 6 } & Within Groups & 34.713 & 202 & 0.172 & \\
\cline { 2 - 6 } MPSKT & Total & 35.238 & 204 & 220 \\
\hline \multirow{2}{*}{ Between Groups } & 0.808 & 202 & 0.404 & 11.729 \\
\cline { 2 - 6 } & Within Groups & 6.956 & 2034 & .000 \\
\cline { 2 - 6 } & Total & 7.763 & 204 & & \\
\hline
\end{tabular}

Table 7. Multiple Comparisons: Tukey HSD

\begin{tabular}{|c|c|c|c|c|c|}
\hline Dependent Variable & School grade & School grade & Mean Difference & Std. Error & $p$ \\
\hline \multirow{6}{*}{ MrB } & \multirow{2}{*}{ Primary } & Lower-secondary & 0.09048 & 0.06785 & .378 \\
\hline & & Upper-secondary & -0.03156 & 0.07261 & .901 \\
\hline & \multirow{2}{*}{ Lower-secondary } & Primary & -0.09048 & 0.06785 & .378 \\
\hline & & Upper-secondary & -0.12204 & 0.07470 & .234 \\
\hline & \multirow{2}{*}{ Upper-secondary } & Primary & 0.03156 & 0.07261 & .901 \\
\hline & & Lower-secondary & 0.12204 & 0.07470 & .234 \\
\hline \multirow{6}{*}{ MPSKT } & \multirow{2}{*}{ Primary } & Lower-secondary & $-0.13909 *$ & 0.03037 & .000 \\
\hline & & Upper-secondary & $-0.11101 *$ & 0.03250 & .002 \\
\hline & \multirow{2}{*}{ Lower-secondary } & Primary & $0.13909 *$ & 0.03037 & .000 \\
\hline & & Upper-secondary & 0.02808 & 0.03344 & .679 \\
\hline & \multirow{2}{*}{ Upper-secondary } & Primary & $0.11101 *$ & 0.03250 & .002 \\
\hline & & Lower-secondary & -0.02808 & 0.03344 & .679 \\
\hline
\end{tabular}


ary teachers show a not significantly different regarding MPSKT $(p=.679>.05)$. This indicates that the MrB among primary, and secondary teachers are relatively same. Furthermore, since a significant difference of MPSKT between primary teachers and secondary teachers (both lower and upper) was found, the score of each group can be compared through the descriptive results, presented in table 4. It was found that the mean score of MPSKT of lower-secondary teachers $(M=2.49, S D=.187)$ is relatively higher when compared with that of primary teachers $(M=2.30, S D=.195)$. Likewise, the mean score of MPSKT of upper-secondary teachers is relatively higher when compared with that of primary teachers $(M=2.46, S D=.167)$. This results could indicate that secondary teachers had better MPSKT than primary teachers.

The results of the quantitative research as described above become the basis of selecting participants in the second-year research. Thus, we selected the only representative from lower-secondary school and primary teachers.

\section{Teachers' MrB: Qualitative Results}

\section{Beliefs about mathematics}

Table 8 summarises primary and secondary teachers' belief about mathematics. The teachers' views are presented from three cases: (1) mathematical skills need to be addressed by someone, (2) relationship between mathematics and real-life, and (3) definition of mathematics.

This is not to generalize which group is more 'problem-solving'. Instead, it tried to zoom in how each group of teachers gives their views on particular issues in domains of mathematics-related beliefs for each of Instrumentalist view, Platonist view, and problem-solving view. The following describes according to cases related to each domain of mathematics-related beliefs.

\section{Definition of mathematics}

Platonist beliefs about what mathematics is were expressed by most of the primary ( 6 teachers) and secondary teachers (10 teachers). A platonist view such as the statement that mathematics is discovered can be observed from S2. "I think the objects of mathematics are created spread throughout this world. The problem is that not all the objects have been found by humans. That is why people only search those objects, which in the future, I believe, there will be many more mathematical objects found." Similarly, P1 asserted this view by expressing their teaching topic. He says, "I do not find anything different from what I learned in mathematics, from the past to the present and even the future. The types of triangles, for example, always consist of, say, isosceles triangle, equilateral triangle, right triangle, and scalene triangle. And, the product of two integers such as negative times always negative positive, remains the same ...". He finally concludes, "The object of mathematics will be remaining the same. The only thing that can change is only about the strategies to solve problem-related to mathematics."

Meanwhile, Instrumentalist beliefs about mathematics are revealed by two primary teachers and two secondary teachers. Generally, they agree that mathematics is a set of rules, procedures, skills that are used to solve any real-life problem, which is line with Ernest's (1989) view that it accentuate the functions of mathematical knowledge on its external world. In this regard, P9 says, "Mathematics is a queen of science, meaning that it is used to solve any problems across disciplines, like physics, chemistry, even social science. That is why when someone is an expert in calculating, executing algebraic or geometrical procedures, statistical skills, etc., he/she will learn other related disciplines better." The problem-solving view, on the other hand, is expressed by only two primary and 1 secondary teacher. This viewpoint out that mathematics is a discipline which emphasizes the development of thinking skills, such as reasoning, critical thinking, and creative thinking. S12, for instance, argues that "The essential thing you need to learn from mathematics is not only about calculating numbers or carrying out some mathematical operations, but also about the skills of thinking critically and creatively or recognizing the pattern of phenomena. Even when you want to decide something, unconsciously, you apply your mathematical thinking."

Interestingly, some teachers seemed to have two beliefs simultaneously. For example, P1 not only agree that mathematics is a static body of knowledge that exists on its own but also agree that it is also a science of understanding pattern represented by symbols. He said, "It needs logic to do with mathematics. However, from year to year, mathematics will not change. The symbols of mathematical operation such as,$+-x$, and : as well as the results of any mathematical operation of particular numbers will be remaining same." Another point of interest is that both primary and secondary teachers espoused their beliefs by exemplifying their evidence from their daily teaching activities. For example, when P10 expressed her Platonist view, she asserted, "From the first year I taught, I never found any change from the results of mathematical operation."

\section{Mathematical skills need to be addressed by learners}

An instrumentalist view emphasizes that skills of calculating and carrying out mathematical procedures are the most important skill an individual should have. S1 gives his view. "People should be able to have a good skill in calculating first before applying a various mathematical formula. Without this skill, they would not be able to think creatively or even critically." Meanwhile, a Platonist view is revealed, for example, by S2. He says, "Understanding various branches of mathematics is important since it will be useful for those who want to learn mathematics seriously, or for those who want to be a mathematician. However, the need for having creative thinking, although it is learned in mathematics, is not the primary focus of learning mathematics." In contrast, a problem-solving view like

Table 8. Primary and secondary teachers' views about the nature of mathematics

\begin{tabular}{|c|c|c|c|c|c|c|}
\hline \multirow{2}{*}{ Cases } & \multicolumn{3}{|c|}{ Primary } & \multicolumn{3}{|c|}{ Secondary } \\
\hline & Instrumentalist & Platonist & Problem-solving & Instrumentalist & Platonist & Problem-solving \\
\hline Definition of mathematics & P5, P9 & $\begin{array}{l}\text { P1, P3, P4, } \\
\text { P10, P6, P7 }\end{array}$ & P2, P8 & $\mathrm{S1}, \mathrm{S} 6$ & $\begin{array}{r}\text { S2, S3, S5, S7, } \\
\text { S8, S9, S10, } \\
\text { S11, S13, S4 }\end{array}$ & $\mathrm{S} 12$ \\
\hline $\begin{array}{l}\text { Mathematical skills need to } \\
\text { be addressed by someone }\end{array}$ & P5, P9, P10 & P3 & $\begin{array}{r}\mathrm{P} 1, \mathrm{P} 2, \mathrm{P} 4, \mathrm{P} 6, \\
\mathrm{P} 7, \mathrm{P} 8\end{array}$ & $\mathrm{~S} 1, \mathrm{S3}, \mathrm{S} 6, \mathrm{~S} 8$ & $\begin{array}{r}\text { S2, S4, S9, } \\
\text { S13 }\end{array}$ & $\begin{array}{r}\mathrm{S} 5, \mathrm{~S} 7, \mathrm{~S} 10, \mathrm{~S} 11, \\
\mathrm{~S} 12\end{array}$ \\
\hline $\begin{array}{l}\text { The relationship between } \\
\text { mathematics and real-life }\end{array}$ & P4, P6, P10 & P3, P5, P9 & $\mathrm{P1}, \mathrm{P2}, \mathrm{P7}, \mathrm{P} 8$ & S1 & $\begin{array}{r}\text { S2, S5, S6, S7, } \\
\text { S8, S9, S10, } \\
\text { S13 }\end{array}$ & S3, S4, S11, S12 \\
\hline
\end{tabular}


expressed by P7 shows that calculating skills and applying the mathematical formula in real life problem mathematics is more than calculating. P7 adds, "It needs understanding thinking skills and catching various patterns of phenomena."

Interestingly, teachers tend to explain their beliefs about the nature of mathematics by giving examples of their teaching experience and personal experience dealing with mathematics. For example, when describing their beliefs about the skills addressed from learning mathematics, they seem to compare the options with their students ability. This is indicated from P1, "Students at primary school are not asked for deals with a very abstract symbol or advanced mathematics topic. Rather, with the basic knowledge of mathematics, they are encouraged to use this knowledge to solve any real-life problem." Comparing with primary teachers, secondary teachers tend to describe their view based on their personal experience, instead of their students' experiences in doing mathematics. P2, for instance, says, "Mathematics teaches calculating. My experience tells you to need to have good calculating skills since in secondary school you will find many formulae that require you to be good in mathematical operation". P3 adds, "a learner would not be able to think mathematics creatively if he/she still have difficulties in certain mathematical procedures. That is why a learner should learn from calculating skills before learning more topics in mathematics such that he/she could think more creatively in solving the problem". Those two personal experiences indicate P2's and P3's hierarchical view about what should be learned in order, i.e. 1) calculating/applying formula, 2) understand various topics of mathematics, 3 ) creative and critical thinking.

The relationship between mathematics and the real-life problem

Instrumentalist view, which gives more attention to the functions of mathematics knowledge on its external world (Ernest, 1989), can be viewed from P1's statement. She says, "Not surprisingly that mathematics learned from elementary school to university will be used to solve any real-life problem. That is why students need first to learn how to calculate and how to use any mathematical formula before trying to solve any real-life problem." In this case, mathematical topics are learned to solve a real-life problem. A different perspective is revealed by P3. He argues, "Maybe there are currently math topics that seem to have not seen its function in the real problem. However,
I'm sure at some point all mathematical topics will be applied in life. This is because all knowledge, including mathematics, is deliberately created to solve everyday problems." Thus, P3 emphasizes his beliefs on the application of mathematics in real life, although such an application is found in the future.

Furthermore, there are three primary teachers and 8 secondary teachers who declared Platonist option, which is there are part of mathematics that can be used to solve any real-life problems and there are other parts that can only be used for further mathematics itself. S2 argued, "I have not found a real-life application of topics such as factorization of algebraic form. It may only be useful to learn any higher mathematical topics, such as for polynomial problem. Meanwhile, topics such as percentage basic operation can be applied in real life, such as for selling-buying activities". In other words, this type of response view mathematics is divided into two part in relation to a real life problem, which is mathematics for mathematics itself and mathematics for real life.

The other view, which corresponds to a problem-solving view, indicates that mathematics and real-life problem are simultaneously used to solve either mathematics problem or real-life problem. P5, for example, gives his view about this matter, "The development of mathematics can start from either real life or pure mathematics itself. When starting from real life, mathematics evolved from solving a real-life problem, in which in this case, mathematics becomes a tool for solving a problem. When starting from mathematics, a real-life application is used as a way to help mathematician to develop higher topics in mathematics. In other words, both mathematics and real-life application could evolve together." P2 argues, "mathematics arises from everyday problems which then the experts formulated into mutually agreed forms. This was later developed in mathematical theories. These theories are used again to solve everyday problems, then from the solution of everyday problems, experts develop higher mathematics, and so on."

\section{Beliefs about mathematics teaching}

Table 9 presents primary and secondary teachers' beliefs about mathematics teaching distributed into seven issues related to mathematics teaching based on Instrumentalist, Platonist, and problem-solving view.

Table 9. Teachers'view about Mathematics teaching

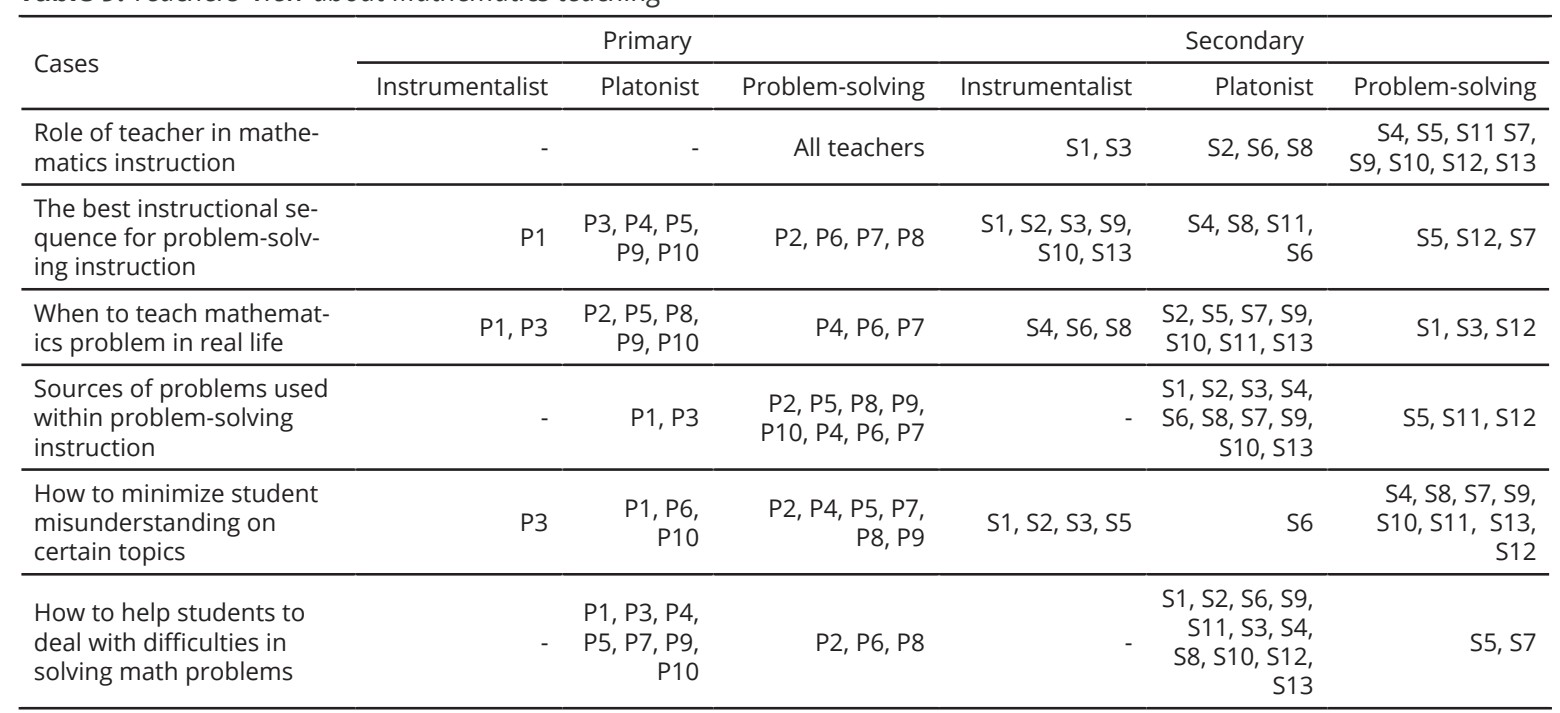


The role of teacher in helping students solve a problem-solving task

In this case, the instrumentalist view is represented as a view that teacher is the transmitter of knowledge and skills. Only two secondary teachers who selected this option and interestingly, no primary teacher who selected this option. In choosing this option, teachers, such as S1 and S3 have a similar reason. S1 pointed out, "As what I learned from my university, I know that this option [problem-solving option] is the best. But, I start to worry about that. I am now teaching at the school where the students are relatively low in mathematics. This makes me somewhat frustrated. Therefore, I change to position my self as a transmitter of math, rather than a facilitator. As such, I often explain certain topic by directly telling the topic related to the mathematics question being solved, rather than letting them find out the nature of the topic by themselves." Thus, S1, as well as S3 related their options with the immediate classroom situation, primarily concerning students' mathematics ability and behavior.

The Platonist view, on the other hand, is shown by a view that teacher is an evaluator of students' work. This option was selected by three secondary teachers. The arguments behind choosing this option, for instances, is argued by S8," by assessing every step of solving a mathematics problem, I will be able to investigate the progress of students' solution steps. This will minimize their errors to get the expected solution finally." S8 asserted, "I feel more satisfied when I could find any mistakes from my students' work then help them clarify the errors." The problem-solving view is indicated by a view that a teacher is a facilitator in exploring students' knowledge and skills. Most secondary teachers, even all primary teachers asserted this option. S8's reasons, i.e. "Teacher as a facilitator, in this case, means teacher give only necessary help when kids are trying to solve a problem. By this way, a teacher could notice the extent to which students understand the problem and construct some strategies to solve the problem."

The precise time to introduce the real-life problem-solving task

There are two questions examined to teachers, i.e. when should you incorporate real-life problem in your teaching sequences? and what is the best teaching sequence you should apply when helping students solve the following problem?

Regarding these questions, an Instrumentalist view is indicated by a view that the teacher should introduce real-life problem after learning mathematical concepts/ procedures related to the problem. For instance, P1 says, "Concept of mathematics should be learned by students first before they start learning to solve a real-life problem. She asserted her view with her responses on the teaching of a division of an integer by a fraction. On the 'rice problem': "every day, a mother needs $3 / 4 \mathrm{~kg}$ of rice for her family. If she has $25 \mathrm{~kg}$ of rice, on what day should she buy more rice?", She responds, "I am not sure they will be able to solve this problem because they haven't yet learned division of fraction such as $2 \div 1 / 2$. They should understand the procedural step of the division of fraction first, which is turning the second fraction upside down, then multiply it with the first fraction." Finally, he closes his statement, "The best method of teaching mathematics is by introducing a particular concept or mathematical formula, followed by giving some exercises, from easy to hard problem, and end up with solving a real-life problem". A secondary teacher, S4, asserts this view by arguing that contextual problem is only suitable to be given at the beginning of the lesson if it is used only for apperception or motivation to show the usefulness of why studying the topic would be learned, instead of being used as resources of learning during the lesson. This implies the need for distinguishing between real life problem used as resources of learning and that as a tool that attracts students' motivation.

Introducing a real-life problem at the beginning of lesson become a statement which indicates teachers' problem-solving view. This view was stated by three primary and 3 secondary teachers. The problem for the secondary teacher: "the price of two glasses and one calculator is the same with the price of one glasses and three calculators, which is IDR500,000. Find the price of a glasses and a calculator", yields at least three views. Instead of first introducing methods of solving the system of linear equations of two variables, namely the method of elimination and substitution for later applied in solving the problem (as stated by S4, S6, S8), or presenting the questions in the easiest form, i.e. in the form of drawings, then asking students to think of a way to find answers by manipulating the images (as stated by S2, S5, S7), the three secondary teachers $(\mathrm{S} 1, \mathrm{~S} 3, \mathrm{S12})$ prefers to select option which invites students to use their own ideas in presenting the problem, either in the form of drawings, diagrams, graphs, or others and use the form of presentation to answer the question. Interestingly, a platonist view like S11 maintains her belief, "It does not matter whether at the beginning or the end of the lesson, that students work actively according to the lesson I have designed."

\section{Sources of problems used in instruction}

There are three types of options which regard this issue. First, problem spontaneously designed during classroom activities or taken from a textbook or the internet. Neither primary nor secondary teachers selected this option. They agree that the quality of mathematics questions suddenly posed during a lesson is not as good as if the mathematics question is intentionally designed before the lesson. S4 argued, "this indicates that the teacher does not prepare the lesson well. The posed mathematics question will not likely elicit students' strategies because the teacher does not anticipate students' various strategies or the question itself is not worth." P5 added, "Problem from the book often gives various model of questions, which could develop students' problem-solving ability. However, students often find difficulties in dealing with such problems such as the problem which is too complex, and no clue." Thus, this view seems aligned with Instrumentalist view in teaching, which leads students to only learn from a particular resource.

Second, a problem designed by teachers. Most secondary teachers selected this option. They agree that the best source problem used in a lesson should be from the teacher. S4, for example, gives his argument, "Teacher knows the type of problem that should be used during a lesson because he/she has set learning sequence based on the expected goals of the lesson he/she already designed. Therefore, the problems can be developed by the teachers themselves." Interestingly, S4 compared his view by arguing that students will not much learn about the topic she is teaching if they are asked to pose a question first. She said, "I am worried that they will be able to design a mathematics problem since they never do it before. I prefer to modify the mathematics problem from book or internet by changing the numerical information or change the question and the information of a problem." Aligned with this view, P3 adds, "The lesson will take longer time if students posed their problem." Thus, all these arguments indicate teachers' platonist view.

Third, the problem designed by students. Most primary teachers ( 8 teachers) and 3 secondary teachers chose this option. The teachers' reasons for choosing this option 
vary around the discussion of students' creativity and attitude. For example, P6 argues, "I often ask my students to pose their question, either individually or in groups. Sometimes, the problem they posed will be discussed in the class discussion which then commented by their friends. I believe it improves students' creativity." Meanwhile, the students' attitude is drawn from the extent to which this activity attracts them to be more active and challenged. P7 gives her opinion, "although sometimes it is difficult for them to design a good problem, they seem motivated in sharing their designed problem in peers or class discussion." These all view, therefore, are aligned with the problem-solving view.

How to clarify students' misunderstanding within an instruction

An instrumentalist view is indicated by a view that teacher should provide more detail explanation on which the misunderstanding occurs. This option only attracted one primary and 1 secondary teacher. P3 argues, "It should better if we show on which parts the student finds difficulties so that we can clarify their work to the correct one immediately. This makes them understand more easily." Aligned with this view, S1 asserts, "Giving a detail explanation on certain parts of a topic will quickly remind them to decide the procedures they should apply." A Platonist view, on the other hand, is shown by a view that a teacher should engages students to be more active in the remaining lesson sequences the teacher designed before. There were only three primary teachers and no secondary teachers who selected this option. P6, in this case, emphasizes her view on the role of teachers to keep students focus on the learning objectives as the teacher has determined. She said, "No matter the students seems noisy in the classroom, as long as they learn what I expect." Meanwhile, a problem-solving view is shown by a view stating that teacher should give the opportunity to discuss their idea to compare which one could fix misunderstandings. Most teachers agree with this option $(6$ primary and 8 secondary teachers). Their idea support that students' difficulties and misunderstanding could be improved when the students share their ideas. In this view, S12 argues, "By providing other students' opportunity to share their idea, not only the students who find difficulties that will take benefits, but also the students who do not find difficulties would have another considerable perspective to solve the problem being examined."

First sentence to help students dealing with difficulties when solving a problem-solving task

To confirm the teachers' response on helping students deal with difficulties in solving a problem-solving task, we asked them to choose one of three options, i.e. "Tell what you think about the problem', which means diagnosing students' difficulties (problem-solving view), "In what parts you think this problem is difficult', which means demonstrating the steps of solving problem on which students think is difficult (Platonist view), and "Look at how I work out this problem", which means demonstrating procedures that solve the problem-solving task (Instrumentalist view)

In this regard, most teachers (7 primary and 11 secondary teachers) selected the Platonist view. There are two main reasons: saving time (for instance $\mathrm{P} 3, \mathrm{P} 4, \mathrm{P} 7$ ) and strengthening a particular step of solving the problem (P5, P9). The first reason, for instance, is indicated by P5. She says, "This will lead me to go directly to what makes them difficult so that I can guide them through a particular prompt". Meanwhile, the latter reason is shown by P5. He says, "Students often get stuck on certain steps of solving the problem. By asking them on what part they find difficulties, students will focus on improving their processes in such a part." To assert his view, P5 also compared with the other two options. He argues, "I think my students will be difficult to explain their answer on this type of question [the problem-solving view] since they are still kids. Furthermore, the scope of this answer is too wide for them although probably it makes them more freedom to express their idea. Meanwhile, surely, this option [the Instrumentalist view] seems to teacher-centered, does not give any chances for students to express their experiences." This might become reasons for all the teacher participants who surprisingly did not select the Instrumentalist view.

\section{Beliefs about mathematics learning}

Table 10 presents primary and secondary teachers' beliefs about how students should learn mathematics distributed into five issues based on Instrumentalist, Platonist, and problem-solving view.

\section{How to improve problem-solving skill}

There are three options each of which represents Instrumentalist, Platonist, and problem-solving view. To improve problem-solving skill, the instrumentalist view (2 primary, 5 secondary) suggest students exercise many times on similar problem to strengthen concepts, while Platonist view (3 primary, 2 secondary) suggest applying procedures demonstrated by teachers/provided in the textbook. Lastly, problem-solving view (5 primary, 6 secondary) suggest students foster their self-strategies based on knowledge and experience. Problem-solving view becomes the most frequent findings from both primary and secondary teachers (5 and six teachers respectively). In this regard, P2, for example, argues, "By this way, I will be able to diagnose the strength and the weaknesses of strategies found by

Table 10. Teachers' view of mathematics learning

\begin{tabular}{|c|c|c|c|c|c|c|}
\hline \multirow{2}{*}{ Cases } & \multicolumn{3}{|c|}{ Primary } & \multicolumn{3}{|c|}{ Secondary } \\
\hline & Instrumentalist & Platonist & Problem-solving & Instrumentalist & Platonist & Problem-solving \\
\hline $\begin{array}{l}\text { The best way for students } \\
\text { to improve problem-solv- } \\
\text { ing skill }\end{array}$ & P3, P7 & $\begin{array}{r}\text { P5, P9, } \\
\text { P10 }\end{array}$ & $\mathrm{P1}, \mathrm{P2}, \mathrm{P4}, \mathrm{P6}, \mathrm{P} 8$, & $\begin{array}{r}\text { S1, S3, S6, S7, } \\
\text { S8 }\end{array}$ & $\mathrm{S} 2, \mathrm{~S} 13$ & $\begin{array}{r}\mathrm{S} 4, \mathrm{~S} 5, \mathrm{~S} 9, \mathrm{~S} 10 \\
\mathrm{~S} 11, \mathrm{~S} 12\end{array}$ \\
\hline $\begin{array}{l}\text { Variety of strategies } \\
\text { students should learn }\end{array}$ & P3, P7 & $\begin{array}{r}\text { P10, P9, } \\
\text { P1 }\end{array}$ & $P 5, P 2, P 4, P 6, P 8$ & $\begin{array}{r}\text { S1, S3, S6, S7, } \\
\text { S9, S2, S13 }\end{array}$ & S8 & $\begin{array}{r}\mathrm{S} 4, \mathrm{~S} 5, \mathrm{~S} 10, \mathrm{~S} 11, \\
\mathrm{~S} 12\end{array}$ \\
\hline $\begin{array}{l}\text { Regarding mathematical } \\
\text { formulas }\end{array}$ & P4, P9 & P3, P10 & $\begin{array}{r}\mathrm{P} 1, \mathrm{P} 2, \mathrm{P} 5, \mathrm{P} 6, \\
\mathrm{P} 7, \mathrm{P} 8\end{array}$ & S7 & $\begin{array}{r}\mathrm{S} 1, \mathrm{~S} 3, \mathrm{~S} 6, \mathrm{~S} 8 \\
\mathrm{~S} 10, \mathrm{~S} 2, \mathrm{~S} 9 \\
\mathrm{~S} 13\end{array}$ & S4, S5, S11, S12 \\
\hline $\begin{array}{l}\text { The use of calculator/ } \\
\text { mathematical software }\end{array}$ & P3, P5, P9, P10 & P1, P4 & P2, P6, P7, P8 & $\begin{array}{r}\mathrm{S} 1, \mathrm{~S} 4, \mathrm{~S} 6, \mathrm{~S} 8 \\
\mathrm{~S} 10\end{array}$ & S3, S7, S9 & $\begin{array}{r}\mathrm{S} 2, \mathrm{~S} 5, \mathrm{~S} 11, \mathrm{~S} 12, \\
\mathrm{~S} 13\end{array}$ \\
\hline $\begin{array}{l}\text { Planning strategies for } \\
\text { problem-solving }\end{array}$ & P2, P3, P7, P8 & P1 & $\begin{array}{r}\mathrm{P} 4, \mathrm{P} 5, \mathrm{P} 6, \mathrm{P9}, \\
\mathrm{P} 10\end{array}$ & $\mathrm{~S} 1, \mathrm{~S} 3, \mathrm{~S} 11$ & S6, S10 & $\begin{array}{r}\text { S2, S4, S5, S7, S8, } \\
\text { S9, S12, S13 }\end{array}$ \\
\hline
\end{tabular}


students. This makes me easier to clarify their misunderstanding." In a similar vein, P8 asserts, "Students have their own strategies, which are not necessarily the same with their teachers' way". This view indicates that teachers tend to believe that exploring students' initial knowledge is important to give what kind of treatment should be provided for the student. However, there is a secondary teacher, i.e. S10, who seems inconsistent in expressing his belief. While agreeing that solving the problems given with students' own knowledge and experience, he also agree that students should still follow the direction of the teacher when experiencing difficulties and more specifically related to mathematical formulas, students must understand the process of deriving a mathematical formula, not just memorizing it.

In addition, teachers with Platonist view tend to believe that students should learn from what their teachers have taught because of two reasons, i.e. teachers' strategy is considered as the best so that it can inspire students to do so (e.g. P5, S2) and teachers' view assuming a lack of students' ability to create their own strategy (e.g. P9, S13). In general, all the teachers with Instrumentalist view, on the other hand, express their beliefs by arguing the benefits of having more exercises related to mathematical concepts, i.e. strengthening prerequisite skill which help students solve a more difficult task.

\section{Variety of strategies students should learn}

In this case, teachers were asked to give their view of the question: if students are provided with some strategies to solve a problem, which should they choose to select? The instrumentalist option regards to the view that students only need to learn one strategy considered as the best by their teachers; Platonist option regards to the view that students need to learn some strategies aligning with the topic they were studying at school by through an active discussion, while problem-solving option regards to the view that students need to learn as many as strategies from any resources. For those who selected Instrumentalist option, reasons emerge around the belief that teacher is deemed as the best person who can identify the focus of learning, including the selection of strategies they should present. This view characterizes teacher's role as the main learning resource for students to learn (teacher-centered). The Platonist view is indicated from the teachers' view stating that students need to discuss with their peers the best strategies that their teacher has presented to find the best according to them. In this regards, P10 argues, "although a teacher should facilitate students by providing some alternative strategies, students should select one strategy based on the results of discussion." Meanwhile the problem-solving view, as revealed by $\mathrm{S} 10$, is indicated from the view of the existence of a chance for other strategies to be used in other problem solutions. S10, in this case, argues, "They (students) should better learn as many as possible strategies. Probably the strategies they finally do not choose for the problem they are solving, but on another occasion, such strategies will likely benefit to solve other types of problems."

\section{The use of mathematical formula}

The teachers were asked to select one of the options: instrumentalist view, i.e. using ready formula provided in the textbook ( 2 primary, 1 secondary), platonist view, i.e. understanding how the formula is derived (2 primary, 8 secondary), or problem-solving view, i.e. not dependent on using certain formula, instead, exploring self-strategies in needed ( 6 primary, 4 secondary). The latter option was mostly selected by teachers. Some reasons are identified around the view that ready formula is trusted so it can be readily applied for solving particular problems; it saves time. The reasons for Platonist option are around the view like revealed by S10, "Students are expected to not only memorize the formula but also understand the process of deriving the formula. This gives benefits when they forget the formula, they can derive again based on their experiences". Meanwhile, reasons for problem-solving view are around the view that was trying to use students' own formula, instead of only using ready formula, could develop student's skills to explore various strategies to solve any problems. Such skills, as S4 asserts, are much more important than only memorizing formula without making a sense with the core idea of the formula. Interestingly, although S7 selected instrumentalist option, he argued that using ready formula is not always bad. He maintains, "sometimes we need to memorize some formula to make our calculation faster so that we could complete all the questions in the provided time." This view points out that the skills of both deriving formulae and using any ready formula within the process of solving a problem is equally important.

\section{The use of calculator in solving a problem}

The instrumentalist option regarding teachers' view on the use of calculator is that calculator is not allowed at all. This option was agreed by four primary and 5 secondary teachers. The Platonist option regards to a view that calculator is allowed when students understand particular concepts/procedures, meanwhile the problem-solving option regards to a view that calculator is allowed provided that the problem being solved is focused on improving problem-solving. While the Platonist option was selected by only one primary and three secondary teachers, the problem-solving view was selected by five primary and 8 secondary teachers. For P1, the person selecting Platonist option, students are allowed to use calculator if only they have learned the basic concepts of certain mathematical operation. She said, "They will not learn a concept if they only rely on calculator. It does not provide an opportunity for students to learn a concept." This view is somewhat different from S1, the person at Instrumentalist view, who maintains that calculator only takes its function in real life application like in trading, instead of in school learning. S1 confirmed, "OK. It can be used only for checking the students answer, whether it is correct or not. I think it does not provide students an opportunity to learn concepts in math." Next, for those choosing problem-solving option believe that because the core skills of learning mathematics are not to calculate, but to reason and to think critically, calculator is allowed. In this regard, S12 argued, "I often ask students to use their calculator, primarily for a math question which encourage them to think using their understanding of a particular concept, although the 'numbers' presented in the question are large."

\section{Teachers' MPSKT: Qualitative Results}

The MPSKT examined to teachers consists of two types, i.e. problem-solving content knowledge (nature of problem, types of mathematical problem, problem-solving process, problem-solving strategies), and pedagogical problem-solving knowledge (setting problem-solving instruction).

\section{Problem-solving content knowledge}

Regarding problem-solving content knowledge, most teachers seem to have a partial understanding, especially about the nature of mathematical problems, types of problems, problem-solving processes, and problem-solving strategies. Teachers were given a set of mathematical questions and were asked to determine whether each of them is a problem or not for their students. Our analysis indicates that most of the primary teachers presume that 
while a problem should be challenging, has no immediate solution/strategies, and interesting, a problem is also a question in which students have insufficient prerequisite related knowledge. For example, P3 says, "This question: find the area bounded by the curves $y=x^{2}-1, x=-4, x=7$, and the $x$-axis' is a problem for my students because they need certain formulas that have never been studied before. The data also shows that most teachers explain the stages required by a solver to solve a problem which simply refers to first three Polya's stages,i.e. understanding a problem, devising a plan, and carrying out the plan with various mentionings. However, only a few indicating their answer leading to the looking back as suggested by experts (e.g. Mason, 2015). In explaining the implementation of the problem-solving process in class, P3 was unable to explain the ideal process to guide students to solve problems as indicated by his statement, "... I asked them to read the questions and listen to what I explained to understand the problem ... then let them choose the method and apply the method ..." This shows that his guidance is somewhat teacher-centered at the beginning of problem-solving.

Regarding types of problem, all the primary teachers did not explicitly mention some possible types as what most secondary teachers mentioned. While the primary teachers only mentioned two examples, namely mathematical problem and word problem, the secondary teachers mentioned, aside from those two, other examples such as open-ended problem, contextual problem, investigative problem, algebraic problem, and geometric problem. However, when interviewed about the idea of giving an example of an open problem, some secondary teachers found difficulties, while others could reveal their idea. For example, S5 expresses his idea about reformulating a more open-ended from a closed-ended problem. He says, "I will reverse the question, as if the area of a rectangle is $225 \mathrm{~cm}^{2}$, then what are the possible sizes? Draw as much as possible an irregular plane with an area of $500 \mathrm{~cm}^{2}$."

\section{Pedagogical problem-solving knowledge}

Chapman (2015) classifies pedagogical problem-solving knowledge into the knowledge of students as problem solvers and instructional practices for problem-solving. The first knowledge includes students' difficulties and students' thinking of what they can do, while the second one includes, for instances, understanding instructional practices for strategies and metacognition, different approaches which are fruitful and not, when and how to intervene during problem-solving process, and what to do when students are stuck. In this report, teachers' pedagogical knowledge were explored through a series of question, "what do you guide students to (1) understand a problem, (2) devise a plan for strategies, (3) carry out the plan, (4) evaluate the results?, and how can you develop your students' problem-solving strategies?

About pedagogical problem-solving knowledge, interestingly, all the teachers seem to indicate sufficiency to explain how problem-solving processes are implemented in learning. It is indicated by the findings that the student learning experiences expected to occur are in the category of consultative teaching, the teaching that supports the idea of giving students opportunity to construct their own idea within problem-solving activities (Blum \& Ferri, 2009), instead of directive teaching, the teaching that seen as an instructor, which support the idea of practicing students on certain problems (Antonius et al., 2007). Some points of consultative teaching were mentioned, for examples, around starting lesson by asking students to understand problems such as choosing relevant and irrelevant information (all teachers), identifying those given and not given but necessary (P3, P4, P5, S3, S4, S5, S9, S13), encouraging to think creatively on each idea in an effort to find the correct mathematical model (all teachers), providing feedback on their strategies and finally ask them to consider whether the solution they found makes sense or not (all teachers, except P2, P3, S3), promoting students to share their solutions and strategies in a discussion session (all teachers).

\section{Discussion}

This study examined Indonesian primary and secondary teachers' beliefs about the three mathematics-related beliefs: nature of mathematics, mathematics teaching, and mathematics learning, and mathematical problem-solving knowledge for teaching. Results found that that there is no significant difference between beliefs across level grade of teaching. In other words, in the same location, the teacher beliefs tend to be the same although they are in the different grade level of teaching. This is in line with the findings that teachers tend to have a similar belief in the same culture, which is culturally located and culturally conditioned (Xenofontos, 2014, 2018). This means that various contextual factors, such as educational policies, the structure of the educational system, and mathematics education in particular, and so on (Wong, Tana, \& Veloo, 2001) have a strong impact on teachers' beliefs to such an extent that more differences can be observed across educational systems, countries, and cultures than within the country addressed each time. Besides, cultural beliefs stated by Cai and Wang (2014), in which teacher beliefs are rooted in, and constrained by, the culture of the society in which the teachers are living and working, give higher impact on forming teacher mathematics-related beliefs rather than that of the different grade level of teaching.

This is not to compare which group of teachers who have a more constructivist belief or a higher understanding of MPSKT between primary and secondary teachers. Rather, this is to compare the unique characteristics drawing on the knowledge and beliefs held by primary teachers and secondary teachers. Regarding teachers beliefs, we found that the teachers' responses are not fully consistent in one domain of beliefs. For example, in this research, the teachers tend to agree that mathematics teaching is important to understand the relevant problem and context, but on the other hand, they also agree that mathematics problem-solving should be done quickly and instantly.

The beliefs about nature of mathematics of the teacher participants were indicated to be neither completely Instrumentalist, Platonist, nor totally problem-solving. Likewise, corresponding beliefs of each of mathematics-related beliefs in the Beswick's summary also were also not totally held by the teacher participants (Zhou as cited in Xie and Cai, 2018). While inconsistencies might occur between the three domains of mathematics-related beliefs, it also occurs between particular issues discussed in one domain. For instances, teachers' view on a particular issue, such as dealing with a mathematical formula, calculator, and which somehow platonist or even instrumentalist, does not support their views about how to teach and learn mathematics based on their own version which is somehow problem-solving. As evidence, P4 believes that the role of teacher in mathematics instruction is a facilitator (problem-solving), but she also believes that to clarify students' difficulties when solving a problem-solving task is by asking the parts of difficulties and then prompting some questions that guide students solve the problem (Platonist), and even she agrees to give some rewards is the best method to increase students' learning motivation (Instrumentalist). Interestingly, although these inconsistencies occur, some of the teacher participants do not fully put their selection only in one option. They have selected the option which best represents their idea about a particular issue, but they have also sometimes somewhat agree 
with the other options, although the degree of preference is not as much as the option he/she selected. In sum, all the abovementioned evidence reflect the view that belief systems are not necessarily logically structured; therefore it is possible for a teacher to hold an inconsistent belief (Andrews and Hatch, 2000; Thompson, 1992; Xenofontos, 2018).

The results bring a wider perspective of the potential factors causing such inconsistencies. First, the fact that some participants understand the nature of the problem without fully understanding the variety of problem-solving strategies points out that insufficient MPSKT leads to different beliefs even within one knowledge domain Second, primary teachers have a various background of education; only a few were graduated from mathematics education program, some were not graduated from primary education; instead, they were graduated from the non-educational program, while secondary teachers were all graduated from the mathematics education program. Therefore, it is possible that the volume of MPSKT the secondary teachers obtained was more than that of the primary teachers did. Thus, teachers' past experience of becoming students influence how they view mathematics (Raymond, 1997). The MPSKT of secondary teachers was found better than those of primary teachers. The possible explanation is that, again, their schooling particularly when they studied at their undergraduate level. In Indonesian teacher education curriculum, institutions which have a responsibility to produce mathematics teachers have some courses both in mathematics and education. This is quite similar to the curriculum provided in primary teacher education. However, the courses of mathematics provided in the secondary program have more various types ranging from school mathematics to pure mathematics, which are not found at primary teacher program.

In giving emphasis on the priority of learning mathematics, teachers across countries also give a different view. While teachers at the U.S within the study of Cai and Wang (2009) put more emphasis on student understanding with concrete examples, and the sample of Chinese teachers put more emphasis on abstract reasoning after using concrete examples, Indonesian teachers at this study put their view on abstract reasoning before using concrete examples or with concrete examples. Many of our samples in the second year project, both primary and secondary teachers, believe that students should learn from abstract reasoning, e.g. by strengthening their mathematical concepts and procedures, before they learned its concrete examples. P1, for instance, believes that it is difficult to put a concrete situation of a real-life problem at the beginning of their lesson for students to solve since the concepts related to such problem is included in some mathematical theories would be discussed. Only a few of them put their emphasis on student understanding with concrete examples. S2 agrees that using concrete examples can be used as a context for learning, which means problem or examples should be put during a learning process, although he does not frequently use concrete examples in his teaching. As he stated regarding the relationship between mathematics and real-life problem, not every math topic has its concrete application in real life; therefore it is difficult to select a good problem for a lesson. In relation to their MPSKT, it is hypothesized to be related to the content knowledge of problem-solving, in which they found difficulties in selecting appropriate problem used in any situation, both for only apperception of a lesson, for being discussed during the lesson, or for being worked af ter having done with the lesson. Thus, the finding that P1 has insufficient knowledge of understanding the nature of problem and identifying types of problem, as well as limited knowledge of problem-solving strategies, is in line with her Instrumentalist view on using concrete exam- ples in a lesson (see Siswono et al., 2017). In other words, this finding supports the view that knowledge and beliefs are not isolated entities, which teacher beliefs may take some roles as a mediator between teacher knowledge and teacher practice (Wilkins, 2008).

In this study, we highlight that beliefs about nature of mathematics were mainly influenced by teachers' experience when learning mathematics at their schooling experience (especially at primary until secondary), while beliefs about teaching and learning were mainly influenced by current reform of curriculum of mathematics for primary and secondary level. As evidence, P1's view about mathematics, i.e. the objects of mathematics will be remaining same over time while strategies used to find out such objects may change, indicates her experiences when learning mathematics at her past schools. Meanwhile, the teachers' hesitant to break their habit, as found on S1's view about teaching problem-solving task, such as teacher dependency on the book dropped by the government, points out that teachers trust on the quality of problems or teaching approach proposed by the book as the product of current curriculum. Additionally, the change of beliefs about teaching mathematics, from traditional beliefs to constructivist beliefs, as exemplified by the story of S1's teaching experiences, indicates that the change of curriculum influence teachers' current view about teaching mathematics. Something to worry about is that they only take a role as curriculum implementer who waits for the instruction as a form of responsibility as the mandate from the government (Purnomo, 2017), in which what they do is not because of what they believe. Instead, it is because of the demands of the current curriculum.

\section{Conclusion}

This study highlight that there is no significant difference between the MrB of primary, lower, and secondary teachers, while there is a significant difference between MPSKT of primary teachers and both lower and upper secondary teacher. However, there is not any significant difference between MPSKT of upper and lower secondary teachers. Also, this study suggests that inconsistencies not only occur between the three domains of MrB but also occurs between particular issues discussed within one domain. Potential factors causing such inconsistencies are identified around insufficient knowledge of particular components of MPSKT and various background of teachers' past education. Also, teachers' experience when learning mathematics affects their beliefs about mathematics, while current reform of mathematics curriculum affects their beliefs about mathematics teaching and learning.

To suggest, since the MPSKT of primary teachers are relatively worse than that of secondary teachers, we stress the importance of encouraging primary teachers to get involved in some professional learning focusing on improving problem-solving knowledge (content and pedagogical). The professional learning could give some problem-solving experiences such as understanding the nature of problem and posing a worthwhile problem (Leavy \& Hourigan, 2019), posing context-based problem (Ekawati et al., 2017; Kohar et al., 2019, Siswono et al., 2018b), or posing problem-solving task to bring such task into a teaching practice (Siswono et al., 2018b).

\section{Acknowledgment}

We want to thank the Ministry of higher education and research of Indonesia on Fundamental Grant in the year 2016-2017 and Stranas Grant in 2018, the Rector of Universitas Negeri Surabaya, and all the participants involved in this study. Our thanks also to the reviewers for the useful feedback. 


\section{References}

Andrews, P., \& Hatch, G. (2000). A comparison of Hungarian and English teachers' conceptions of mathematics and its teaching. Educational Studies in Mathematics, 43(1), 31-64. https://doi.org/10.1023/A:1017575231667

Antonius, S., Haines, C., Jensen, T. H., Niss, M., \& Burkhar$\mathrm{dt}, \mathrm{H}$. (2007). Classroom activities and the teacher. In W. Blum, P. L. Galbraith, H.-W. Henn, \& M. Niss (Eds.), Modelling and applications in mathematics education (pp. 295-308). New York: Springer. https://doi.org/10.1007/978-0-387-29822-1_31

Ary, D., Jacobs, L. C., Irvine, C. K. S., \& Walker, D. (2018). Introduction to research in education. Cengage Learning.

Beswick, K. (2012). Teachers' beliefs about school mathematics and mathematicians' mathematics and their relationship to practice. Educational Studies in Mathematics, 79(1), 127-147. https://doi. org/10.1007/s10649-011-9333-2

Blum, W., \& Ferri, R. B. (2009). Mathematical modelling: can it be taught and learned? Journal of Mathematical Modelling and Application, 1(1), 45-58. http:// gorila.furb.br/ojs/index.php/modelling/article/ download/1620/1087

Bray, W. S. (2011). A collective case study of the influence of teachers' beliefs and knowledge on error-handling practices during class discussion of mathematics. Journal for Research in Mathematics education, 42(1), 2-38. https://www.jstor.org/stable/10.5951/ jresematheduc.42.1.0002

Cai, J. (2004). Why do US and Chinese students think differently in mathematical problem-solving?: Impact of early algebra learning and teachers' beliefs. The Journal of Mathematical Behavior, 23(2), 135-167. https://doi.org/10.1016/j.jmathb.2004.03.004

Cai, J., \& Wang, T. (2009). Conceptions of effective mathematics teaching within a cultural context: Perspectives of teachers from China and the United States. Journal of Mathematics Teacher Education, 13(3), 265-287. https://doi.org/10.1007/s10857$009-9132-1$

Chapman, O. (2015). Mathematics teachers' knowledge for teaching problem solving. LUMAT (2013-2015 Issues), 3(1), 19-36. http://www.lumat.fi/index.php/ lumat-old/article/download/38/28

Correa, C. A., Perry, M., Sims, L. M., Miller, K. F., \& Fang, G. (2008). Connected and culturally embedded beliefs: Chinese and US teachers talk about how their students best learn mathematics. Teaching and Teacher Education, 24(1), 140-153. https://doi. org/10.1016/j.tate.2006.11.004

Ekawati, R., Kohar, A. W., \& Hartono, S. (2017). Experts' notion and students' responses on context-based mathematics problem. Journal of Engineering Science and Technology (JESTEC), 53-64.

Ekawati, R., Lin, F. L., \& Yang, K. L. (2015). Developing an instrument for measuring teachers'mathematics content knowledge on ratio and proportion: a case of Indonesian primary teachers. International Journal of Science and Mathematics Education, 13(1), 1-24. https://doi.org/10.1007/s10763-014-9532-2
Ernest, P. (1989). The impact of beliefs on the teaching of mathematics. Mathematics teaching: The state of the art, 249, 254. http://webdoc.sub.gwdg.de/edoc/e/ pome/impact.htm

Fusch, P. I., \& Ness, L. R. (2015). Are we there yet? Data saturation in qualitative research. The qualitative report, 20(9), 1408-1416. https://nsuworks.nova. edu/tqr/vol20/iss9/3/

Glaser, B. (2017). Discovery of grounded theory: Strategies for qualitative research. Routledge.

Handal, B., \& Herrington, A. (2003). Mathematics teachers' beliefs and curriculum reform. Mathematics education research journal, 15(1), 59-69. https://doi. org/10.1007/BF03217369

Kohar, A. W., Wardani, A. K., \& Fachrudin, A. D. (2019). Profiling context-based mathematics tasks developed by novice PISA-like task designers. Journal of PhysicS: Conference Series (Vol. 1200, No. 1, p. 012014). IOP Publishing. https://iopscience.iop.org/article/10.1088/1742-6596/1200/1/012014/meta

Leavy, A., \& Hourigan, M. (2019). Posing mathematically worthwhile problems: developing the problem-posing skills of prospective teachers. Journal of Mathematics Teacher Education, 1-21. https://doi. org/10.1007/s10857-018-09425-w

Miles dan Huberman. (1994). Qualitative data analysis: An exposed sourcebook 2nd. London: SAGE Publication Ltd.

Ministry of Education (MoE) (2016). Peraturan Menteri Pendidikan dan Kebudayaan Republik Indonesia Nomor 21 Tahun 2016 tentang Standar Isi Pendidikan Dasar dan Menengah. (Minister of Education and Culture Regulation Number 21 of 2016 concerning Standard Content for Primary and Secondary Education). Jakarta: MoE. https://bsnp-indonesia. org/wp-content/uploads/2009/06/Permendikbud_ Tahun2016_Nomor021.pdf

$\mathrm{Ng}$, D. (2011). Indonesian primary teachers' mathematical knowledge for teaching geometry: implications for educational policy and teacher preparation programs. Asia-Pacific Journal of Teacher Education, 39(2), 151-164. https://doi.org/10.1080/1359866X.2011.560648

Perry, B., Wong, N. Y., \& Howard, P. (2006). Comparing primary and secondary mathematics teachers beliefs about mathematics, mathematics learning and mathematics teaching in Hong Kong and Australia. In Mathematics Education in Different Cultural Traditions-A Comparative Study of East Asia and the West (pp. 435-448). Springer US. https://doi. org/10.1007/0-387-29723-5_26

Purnomo, Y. W., Suryadi, D., \& Darwish, S. (2016). Examining pre-service elementary school teacher beliefs and instructional practices in mathematics class. International Electronic Journal of Elementary Education, 8(4), 629-642. https://www.iejee.com/index. php/IEJEE/article/download/137/134

Purnomo, Y. W. (2017). The complex relationship between teachers' Mathematics-related beliefs and their Practices in Mathematics Class. The New Educational Review, 47(1), 200-210. http://www.educationalrev.us.edu.pl/dok/volumes/tner_1_2017b.pdf\#page $=200$ 
Purnomo, Y. W., Aziz, T. A., Pramudiani, P., Darwis, S., \& Suryadi, D. (2018, January). Potential characteristics that relate to teachers mathematics-related beliefs. In Journal of Physics: Conference Series (Vol. 948, No. 1, p. 012062). IOP Publishing. https://iopscience. iop.org/article/10.1088/1742-6596/948/1/012062/ pdf

Raymond, A. M. (1997). Inconsistency between a Beginning Elementary School Teacher's Mathematics Beliefs and Teaching Practice. Journal for Research in Mathematics Education, 28(5), 550-76. https:// www.jstor.org/stable/749691

Ren, L., \& Smith, W. M. (2017). Teacher characteristics and contextual factors: links to early primary teachers' mathematical beliefs and attitudes. Journal of Mathematics Teacher Education, 1-30. https://doi. org/10.1007/s10857-017-9365-3

Siswono, T. Y. E., Kohar, A. W., Kurniasari, I., \& Astuti, Y. P. (2016). An Investigation of Secondary Teachers' Understanding and Belief on Mathematical Problem Solving. In Journal of Physics: Conference Series (Vol. 693, No. 1, p. 012015). IOP Publishing. https://iopscience.iop.org/article/10.1088/1742-6596/693/1/012015/pdf

Siswono, T. Y. E., Kohar, A. W., \& Hartono, S. (2017). Secondary Teachers' Mathematics-related Beliefs and Knowledge about Mathematical Problem-solving. In Journal of Physics: Conference Series (Vol. 812, No. 1, p. 012046). IOP Publishing. https://iopscience. iop.org/article/10.1088/1742-6596/812/1/012046/ pdf

Siswono, T.Y.E., Kohar, A.W., Kurniasari, I., \& Hartono, S. (2018a). Inconsistency among beliefs, knowledge, and teaching practice in mathematical problem solving: A case study of a primary teacher. Southeast Asian Mathematics Education Journal, 7(2), 2739. https://www.qitepinmath.org/en/publications/ journal/seamej-vol-7-number-2-2017/

Siswono, T. Y. E., Kohar, A. W., Rosyidi, A. H., \& Hartono, S. (2018b). Searching for authentic context in designing PISA-like mathematics problem: From indoor to outdoor field experience. In Journal of Physics: Conference Series (Vol. 953, No. 1, p. 012197). IOP Publishing. https://iopscience.iop.org/article/10.1088/1742-6596/953/1/012197/pdf

Spangenberg, E. D., \& Myburgh, C. (2017). Comparing south african female and male pre-Service teachers' beliefs about the nature of mathematics. Africa Education Review, 14(2), 140-155. https://doi.org /10.1080/18146627.2017.1292828

Stake, R. E. (2005). Qualitative Case studies. In N. K. Denzin \& YS Lincoln (Eds.), Handbook of qualitative research (pp. 443-466).

Tatto, M. T., Peck, R., Schwille, J., Bankov, K., Senk, S. L., Rodriguez, M., ... \& Rowley, G. (2012). Policy, Practice, and Readiness to Teach Primary and Secondary Mathematics in 17 Countries: Findings from the IEA Teacher Education and Development Study in Mathematics (TEDS-MM). International Association for the Evaluation of Educational Achievement. Herengracht 487, Amsterdam, 1017 BT, The Netherlands. http://files.eric.ed.gov/fulltext/ED542380. pdf
Thompson, A. G. (1992). Teachers' beliefs and conceptions: A synthesis of the research. In D. A. Grouws (Ed.), Handbook of research on mathematics teaching and learning (pp. 127-146). New York: Macmillan. https://psycnet.apa.org/record/1992-97586-007

Van Zoest, L. R., Jones, G. A., \& Thornton, C. A. (1994). Beliefs about mathematics teaching held by pre-service teachers involved in a first grade mentorship program. Mathematics Education Research Journal, 6(1), 37-55. https://doi.org/10.1007/BF03217261

Wang, T., \& Cai, J. (2007). Chinese (Mainland) teachers' views of effective mathematics teaching and learning. ZDM, 39(4), 287-300. https://doi.org/10.1007/ s11858-007-0030-7

Wilkins, J. L. (2008). The relationship among elementary teachers' content knowledge, attitudes, beliefs, and practices. Journal of Mathematics Teacher Education, 11(2), 139-164. https://doi.org/10.1007/ s10857-007-9068-2

Wong, K. Y., Tana, Z. B. H. M., \& Veloo, P. (2001). Situated Sociocultural Mathematics Education: Vignettes From Southeast. Sociocultural research on mathematics education: an international perspective, 113.

Xie, S., \& Cai, J. (2018). Chinese Teachers' Beliefs About Mathematics Teaching. In The 21st Century Mathematics Education in China (pp. 413-427). Springer, Berlin, Heidelberg. https://doi.org/10.1007/978-3662-55781-5_20

Xenofontos, C. (2014). The cultural dimensions of prospective mathematics teachers' beliefs: Insights from Cyprus and England. Preschool and Primary Education, 2, 3-16. http://dx.doi.org/10.12681/ppej.85

Xenofontos, C. (2018). Greek-Cypriot elementary teachers' epistemological beliefs about mathematics. Teaching and Teacher Education, 70(1), 47-57. https:// doi.org/10.1016/j.tate.2017.11.007

Yin, R. K. (2003). Case study research and applications: Design and methods (Third Edition). Sage publications. 